\title{
MASA Syndrome
}

National Cancer Institute

\section{Source}

National Cancer Institute. MASA Syndrome. NCI Thesaurus. Code C129930.

An X-linked recessive condition caused by mutation(s) in the L1CAM gene, encoding neural cell adhesion molecule L1. It is characterized by mental retardation, aphasia, shuffling gait and adducted thumbs. 